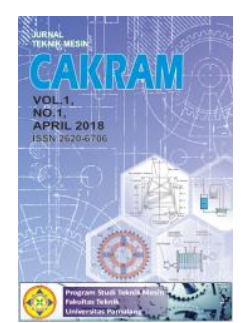

\title{
SIMULASI PENGUKURAN DIMENSI SLIDER PADA MESIN CETAK PLASTIK MENGGUNAKAN ALAT UKUR COORDINATE MEASURING MACHINE (CMM)
}

\author{
Nurjaya $^{1}$ \\ IProgram Studi Teknik Mesin, Fakultas Teknik, Universitas Pamulang \\ E-mail : Jnur40373 @gmail.com \\ Masuk : 6 Februari 2021 \\ Direvisi : 13 Maret 2021 \\ Disetujui : 17 Maret 2021
}

\begin{abstract}
Abstrak: Mesin cetak (mold) merupakan suatu mesin yang memiliki ruang atau tempat plastic cair panas, yang dinjeksikan dengan mesin injeksi untuk dibentuk menjadi produk plastic tertentu sesuai bentuk ruang. Mesin cetak ini memiliki banyak komponen, salah satunya Slider. Komponen ini berkerja dengan cara maju dan mundur yang digerakan oleh hidrolik. Pada umumnya, komponen ini saat berkerja sering kali mengalami kerusakan, berupa gesekan pada permukaan yang disebabkan dimensi yang tidak sesuai. Untuk menghindari hal tersebut perlu dilakukan pengukuran menggunakan alat ukur tiga dimensi (Coordinat Measuring Machine) yang memiliki ketelitian tinggi.
\end{abstract}

Kata kunci : Slider, Coordinat Measuring Machine, Graphics of element

Abstract: A molding machine (mold) is a machine that has a space or a place for hot liquid plastic, which is injected with an injection machine to form certain plastic products according to the shape of the room. This printing machine has many components, one of which is a slider. This component works by means of forward and backward driven by hydraulics. In general, these components when working often experience damage, in the form of friction on the surface caused by inappropriate dimensions. To avoid this, it is necessary to measure using a three-dimensional measuring device (Coordinat Measuring Machine) which has high accuracy.

Keywords: Sleder, Coordinate Measuring Machine, Graphics of element

\section{PENDAHULUAN}

Dunia industti yang terus berkembang dan diikuti oleh kemajuan teknologi yang sangat pesat saatini, sehingga hampir diseluluh perusahaan industry sudah mampu membuat mesin cetak (mold) sendiri, sehingga setiap perusahaan dituntut untuk terus meningkatkan kualitas produk, salah satunya pada bagian dimensi produk, khususnya slider. Slider pada mesin cetak plastik merupakan jenis permukaan yang dapat membentuk atau mencetak produk yang memiliki bentuk geometri undercut yang tidak bisa dibentuk oleh core atau cavity, komponen ini berkerja maju dan mundur secara horizontal.[1].

Pada saat merancang atau mendisain slider, diperlukan kegiatan inpeksi. Inpeksi merupakan proses penentuan kesesuaian antara luaran (output) tehadap speksifikasi atau standar [2]. Proses inpeksi ini menggunakan alat ukur tiga dimensi, karena komponen ini memiliki bentuk permukaan yang rumit, Sehingga alat ukur konvensional seperti jangka sorong dan micrometer belum cukup untuk mendukung pembuatan komponen tersebut. 
Pada proses pengukuran slider mesin cetak plastik (mold) dilakukan setelah proses electrical discharge machining selesai. Proses pengukuran dibagi menjadi tiga proses yaitu. CMM, Contour dan Roughness dimana penyimpangan terbesar dari ketiga proses[3]. Rekaman hasil ukur pada proses inspeksi dapat disimpan rentang waktu tertentu agar dapat digunakan kembali untuk menganalisa serta mengetahui kecenderungan kualitas dan kebutuhan, keefektifan dan tindakan koreksi pada instansi atau perusahaan[4].

Hasil pengukuran pada benda kerja dengan alat ukur kemudian dibandingkan dengan gambar kerja lalu hasil ukur dapat disimpan dan dicetak menggunakan perangkat lunak sesuai kebutuhan.

\section{METODOLOGI}

Bahan atau benda kerja yang akan digunakan dalam pembahasan ini adalah slider mesin cetak plastik (mold) dan alat ukur Coordinat Measuring Machine. Pengumpulan data pada bahan uji secara visual dengan mengunakan software atau aplikasi Uni Graphic. Berikut ini adalah alir diagram penelitian:

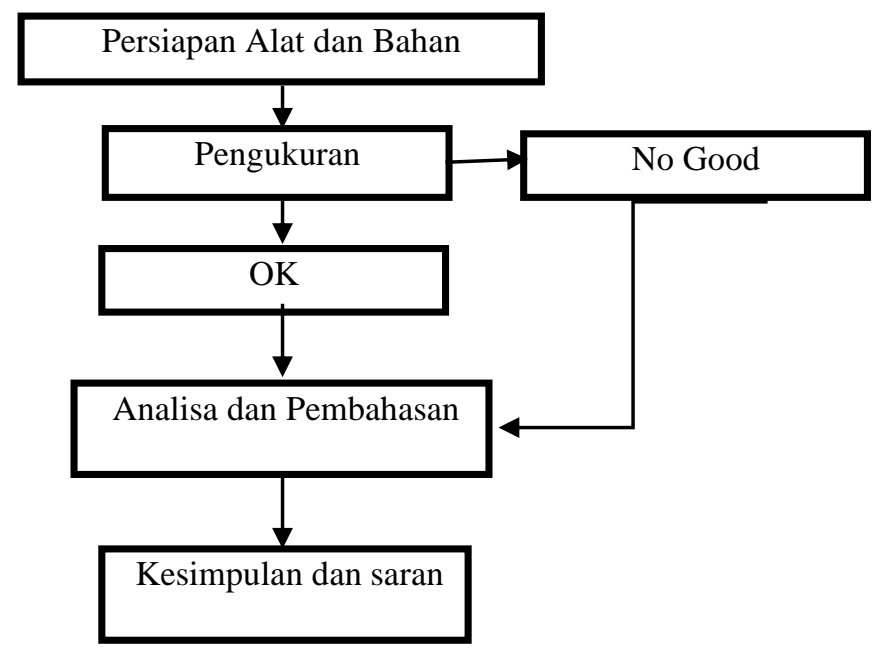

Gambar 1. Diagram alir penelitian

\section{HASIL DAN PEMBAHASAN}

Coordinate meansuring machine adalah alat ukur metrologi yang dapat menghasilkan koordinat tiga dimensi dan dapat ditambahkan perangkat komputer untuk menganalisa kesesuaian antara hasil pengukur terhadap speksifikasi[5]. Dengan adanya perangkat lunak atau PC pada mesin ukur CMM, menjadikan proses pengukuran menjadi lebih akurat dan cepat. Program di perangkat lunak akan menanyakan setiap aktifitas yang akan dilakukan oleh operator mesin alat ukur pada saat proses pengukuran. Beberapa keunggulan yang diberikan oleh perangkat lunak [5]:

a. Konversi satuan antara mm dan inchi

b. Dimensi langkah sumbu X, Y, dan Z

c. Pemilihan basic pengukuran dan penyetelan kembali alat ukur

d. Titik pusat lingkaran atau diameter.

e. Menyimpan file dan membuka kembali file kerja.

f. Memasukan nilai dimensi dalam dari dimensi toleransi dalam (-)

g. Memasukan nilai dimensi luar dari dimensi luar (+)

Mesin alat pengukur ini digunakan untuk mengukur benda kerja tiga dimensi dalam system koordinat kartesian. Kemudian data tersebut dikonversikan menjadi data ukuran seperti posisi, diameter, jarak, sudut, dan sebagainya. Secara 
sederhana prinsip kerja CMM adalah membaca perubahahan posisi tersebut kemudian direkam dan diproses menjadi data hasil pengukuran menggunkan software yang telah terintegrasi dalamCMM[6]. Berikut ini adalah komponen-komponen dari CMM

a. Working Table, yaitu tempat untuk meletakan benda kerja yang akan diukur.

b. Probe, yaitu bagian dari CMM yang berfungsi sebagai trigger bagi CMM untuk merekam posisi yang akan disentuh atau penunjuk area benda kerja yang akan diukur. Pada Sistem probe merupakan salah satu bagian penting yang perlu diperhatikan, hal ini karena sistem probe sebagai pendeteksi dan mengukur geometri [7]

c. Vertical dan Horizontal slide, yang berfungsi sebagai landasan gerak probe.

d. Computer, sebagai controller interface antara mesin CMM dengan PC, yang terintegrasi dengan software untuk menampilkan data-data coordinate.

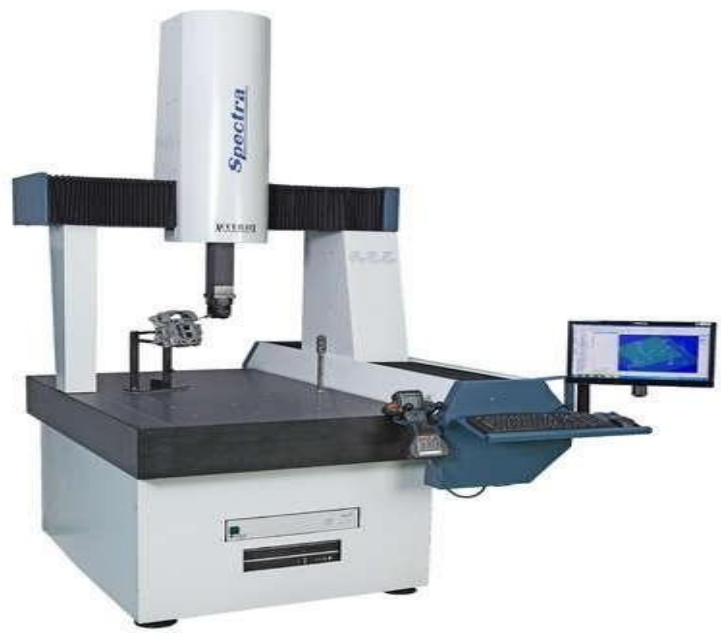

Gambar 2. Bentuk fisik CMM[8]

\section{Benda kerja bahan ukur (slider)}

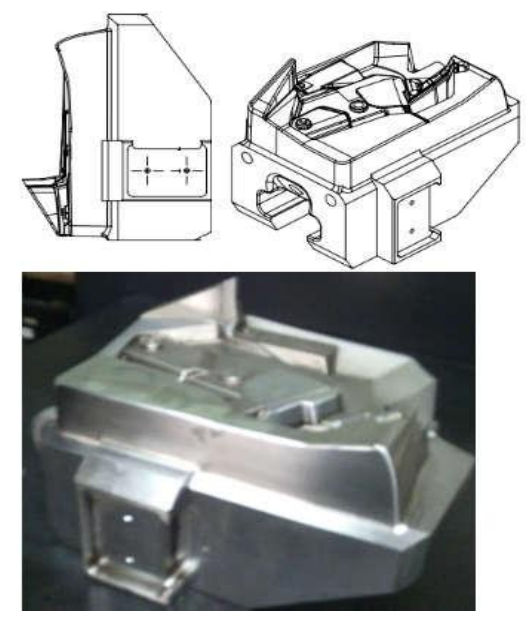

Gambar 3. Slider

\section{Pengukuran}

Alat mesin ukur CMM dapat dioperasikan secara manual atau otomatis dikendalikan oleh komputer. Pengukuran ditentukan oleh probe yang terpasang pada sumbu mesin tersebut (lihat gambar 2). Selain memindahkan probe sepanjang sumbu X, Y, dan Z, mesin CMM juga memungkinkan sudut probe dikontrol untuk pengukuran permukaan yang sulit dijangkau [9]. 
Beberapa contoh fitur pengopersian mesin CMM untuk kategori pengukuran dimensi adalah sebagai berikut[10]:

a. Jarak linier

Jarak internal dan eksternal dengan batas yang dapat diakses secara langsung oleh probe untuk diukur dengan probe berbentuk silinder atau bola, seperti pada Gambar 4
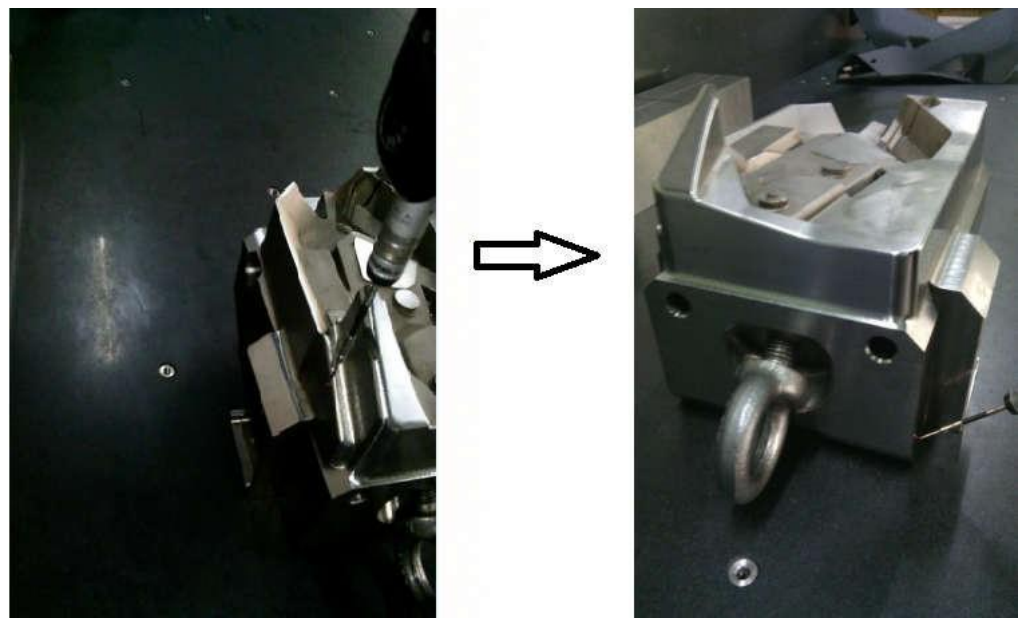

Gambar 4. Pengukuran jarak linier

b. Posisi koordinat dua dimensi

Pengukuran area lubang umumnya berbentuk lingkaran, pada pengukuran ini mengacu pada titk pusat lingkaran, seperti pada gambar berikut.

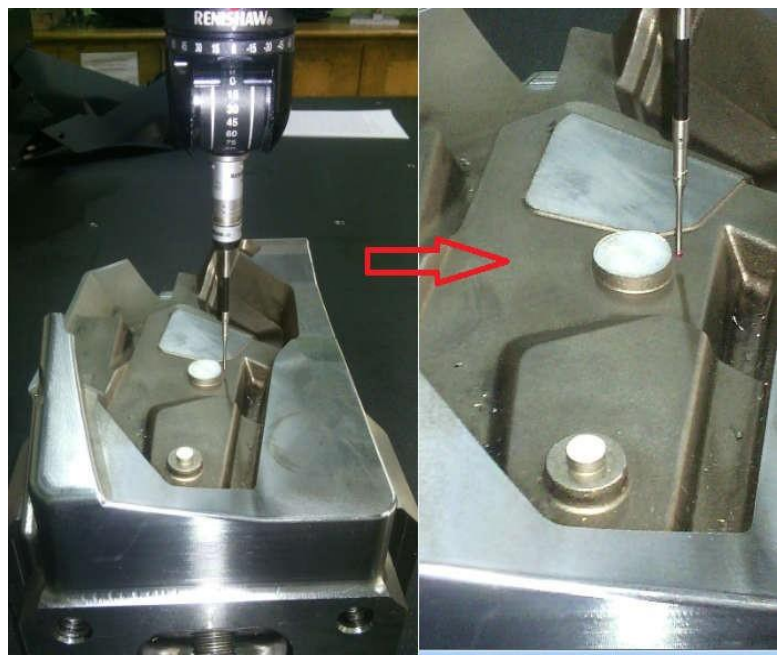

Gambar 5. Pengukuran lingkaran 


\section{c. Ketinggian}

Penukuran ketinggian dilakukan dengan membandingkan bidang basic atau titik acuan tegak lurus dengan titik ukur dimensi pada benda kerja searah sumbu Z, seperti pada gambar 6.

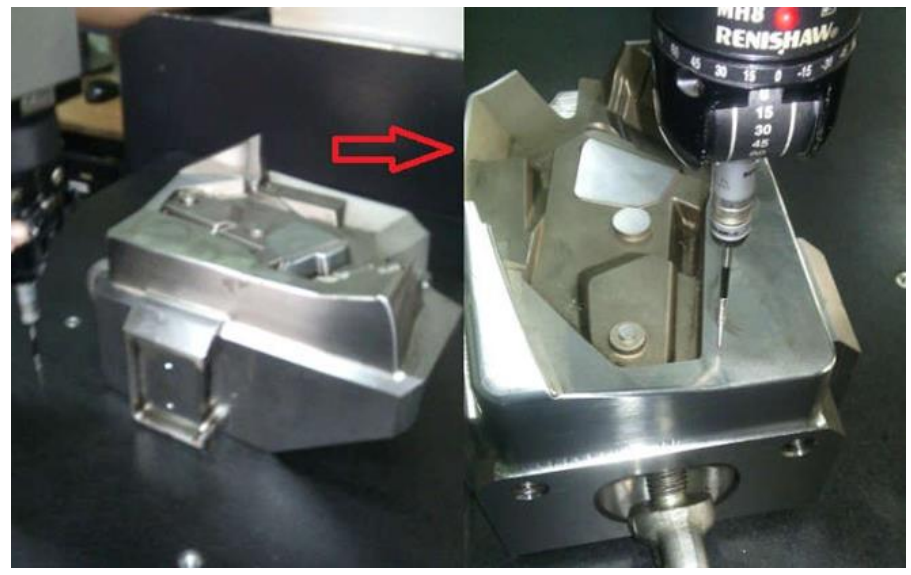

d. Pengukuran sudut dan tirus

Gambar 6. Pengukuran ketinggian

Pengukuran sudut atau tirus dilakukan dengan mengukur area atau bidang ukur terhadap basic, seperti terlihat pada gambar 7.

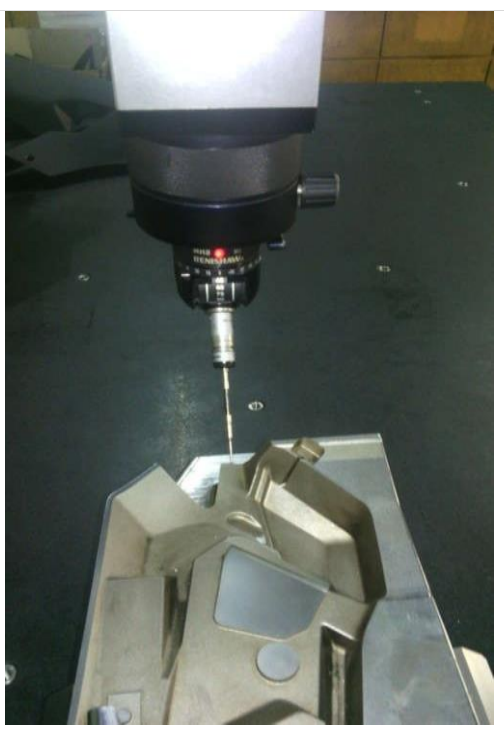

Gambar 7. Pengukuran sudut atau tirus

e. Membandingkan Hasil ukur

Membandingkan atau mengkonversi hasil ukur merupakan proses akhir dari semua tahapan mulai dari pengukukuran jarak linier, pengukuran lubang, sudut atau tirus dan ketinggian. Proses ini dilakukan dengan membandingkan hasil pengukuran dengan probe pada CMM dengan dimensi pada gambar disain 3D slider untuk dievaluasi dan dianalisa dari hasil dimensi proses machining $\mathrm{CNC}$ sehingga angka tersebut dapat diketahui seberapa besarnya penyimpangannya. 


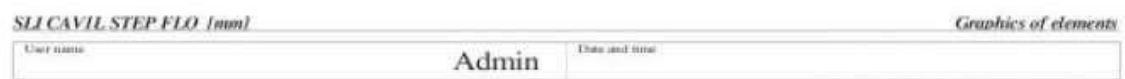

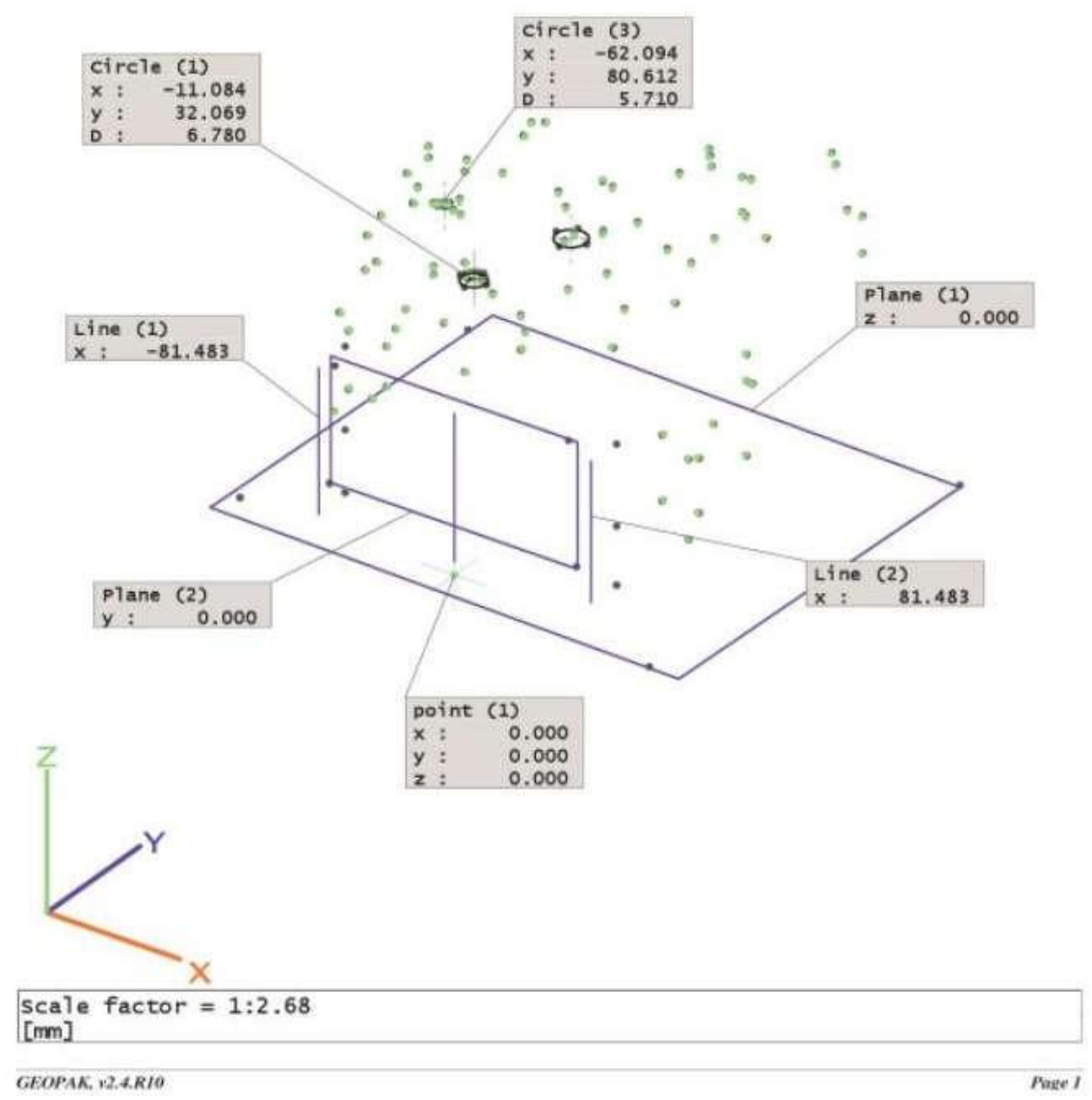

Gambar 8. Posisi basic sumbu XYZ

Gambar 8 menunjukan posisi basic sumbu XYZ untuk memulai proses pengukuran, Line X (1) dan Line X (2) merupakan basic titik bantu untuk mencari titik tengah atau nol (point 1) pada benda kerja yang akan menjadi titik awal probe bergerak ke arah sumbu XYZ sesuai dengan arah world coordinate sistem (WCS).

Pada Gambar 9 dibawah merupakan hasil pengukuran CMM pada benda kerja yang kemudian hasil tersebut akan dibandingkan dengan dimensi pada gambar rancangan atau disain slider, jika nilai tersebut masih dalam batas atau range toleransi, maka part atau benda kerja tersebut dalam kondisi baik, sehingga part tersebut dapat dipasang (assemble) dan berfungsi dengan baik. 


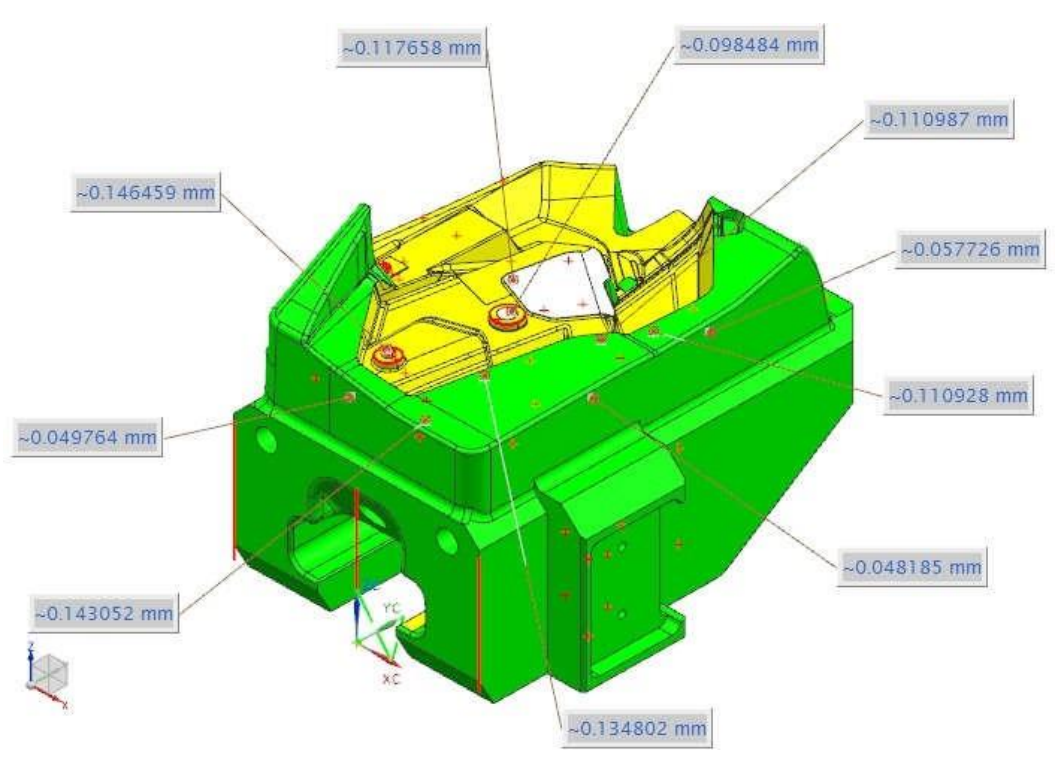

Gambar 9. Check point

\section{KESIMPULAN}

Berdasarkan hasil simulasi pengukuran perancangan Slider dengan menggunakan alat ukur tiga dimensi atau CMM maka dapat disimpulkan bahwa :

1. Simulasi pengukuran slider dengan menggunakan CMM di atas sangat efektif untuk mengetahui bentuk geometri permukaan suatu part benda kerja atau komponen mesin cetak (Mold) sehingga dapat mengurangi resiko kerusakan Slender pada saat berkerja.

2. Pada simulasi pengukuran slider di atas hasil data dapat ditampilkan secara visual menggunakan perangkat lunak yang terpasang pada mesin CMM.

3. Dengan simulasi pengukuran slider menggunakan alat ukur CMM ini dapatdihasilkan nilai ukur yang lebih akurat karena alat ukur ini memiliki keakuratan yang tinggi yakni $0.002 \mathrm{~mm}$.

\section{DAFTAR PUSTAKA}

[1] Firdaus, M, 2017, Desain dan Optimasi Injection Mold dengan Sistem Slider pada Produk Hardcase Handphone. Jurnal Rotasi - Vol. 19, No. 4, Oktober 2017, pp. 217 - 225.

[2] Juran, J.M.,Gryna, Frank M.,"Qualty Planning and Analysis", (1993) McGraw-Hill inc.

[3] http://repository.president.ac.id/bitstream/handle. Diakses pada tanggal 28 Februari 2021

[4] https://metalextra.com/coordinate-measuring-machine-cmm. Diakses pada tanggal 27 Februari 2021

[5] Doston, C., Harlow, R., Thompson, R., "Fundamentals of Dimensional Metrology 4E", (2003) Delman Learning

[6] http://www.dynatech-int.com/id/artikel/bagaimana-cara-menggunakan-alat-ukur-cmm. Diakses pada tanggal 28 Maret 2021

[7] https://microscope.id/id/articles/detail/inspeksi-cmm-probes. Diakses pada tanggal 27 Februari 2021

[8] https://m.indiamart.com/proddetail/3d-coordinate-machines. Diakses pada tanggal 31 Januari 2021 
Jurnal Teknik Mesin: CAKRAM 2021

Nurjaya, Simulasi Pengukuran Dimensi Slider Pada Mesin Cetak Plastik Menggunakan Alat Ukur Coordinate Measuring Machine (CMM)

[9] https://wilter.co.id/coordinate-measuring-machine-cmm. Diakses pada tanggal 28 Februari 2021

[10] Faragon, F.T., Curtis,. M. A., "Handbook of Dimensional Meansurement Third Edition”, (1994) Industrial press inc 